\title{
A Socio-Spatial Analysis of Land Use Dynamics and Process of Land Intervention in the Peri-Urban Areas of Bahir Dar City
}

\author{
Abebe Mengaw Wubie ${ }^{1,2, *(D)}$, Walter T. de Vries ${ }^{2}$ and Berhanu Kefale Alemie ${ }^{1}$ \\ 1 Institute of Land Administration, Bahir Dar University, Bahir Dar P.O. Box 79, Ethiopia; \\ berhanu.kefale@bdu.edu.et \\ 2 Department of Aerospace and Geodesy, Technische Universität München, 85748 München, Germany; \\ wt.de-vries@tum.de \\ * Correspondence: Abebe.Mengaw@bdu.edu.et; Tel.: +251912106213
}

Received: 10 October 2020; Accepted: 4 November 2020; Published: 15 November 2020

\begin{abstract}
The contemporary urbanization and its implication to land use dynamics especially in the peri-urban areas are emerging as a cross-cutting theme in policy debates and scientific discourse. As most cities in developing countries, including Ethiopia, are experiencing continuous expansion of built-ups and dynamic land use changes, monitoring and an in-depth analysis of the past, present and future predictions of these changes are important for a holistic understanding of the problem, its consequence, and to regulate proper land use intervention options. Thus, the main objective of this research is to assess land use dynamics and processes of land intervention in the peri-urban areas of Bahir Dar city using a socio-spatial analysis. It assesses to what extent the existing peri-urban land intervention processes and land use decisions are effective in combating and controlling unwanted land use changes. Primary socio-economic data were collected using questionnaires, focus group discussions (FGDs) and key informant interviews; in addition, spatial data including Landsat and Sentinel imageries of 1993, 2001, 2011 and 2020 were utilized. Land use/land cover (LULC) classes were computed using the integration of spectral and object-based image classification techniques. The results signal that built-ups are expanding horizontally with unpredicted patterns. This is because the existing land intervention processes are lacking effectiveness to govern the spatial patterns of built-ups. The results further depict that processes of land use intervention do not only determine horizontal urban expansion but also determine the nature of people-to-land relationships, which involve both formal and informal processes. This creates haphazard, disputed and unregulated land use systems in peri-urban areas of Bahir Dar. The socio-spatial methodology applied in this research is effective in monitoring both the spatial and social dimensions of land use changes. The spatial results effectively demonstrate the dynamics of land uses; whereas, the social analysis supports understanding of the processes of land use interventions. In conclusion, monitoring processes of land use interventions are key policy and decision making directions to regulate and manage land use dynamics in the peri-urban area.
\end{abstract}

Keywords: spatial patterns; built-up expansion; land use dynamics; land intervention; effectiveness; socio-spatial analysis; peri-urban

\section{Introduction}

Rapid urban expansion, land use dynamics and land governance problems are 21st century concerns and cross-cutting challenges in developing countries [1-5]. These challenges are manifested through a high demand for housing, informal urban expansion, inefficiencies and delays in spatial and 
regional planning, uncontrolled urban population growth, and weak institutional arrangements [6-8]. The rate of urbanization in developing countries is more than twice the world's urban growth rate [9]. Most notably, the African urban population is projected to triple by 2050 [10] and nearly three-quarters of Africa's urban population will live in slums and informal settlements [11,12]. These statistics call for a concerted response.

Ethiopia is one of the African countries that faces these challenges as well. Statistical reports on Ethiopia reveal that its cities are growing with nearly $5 \%$ on average, which is even higher than other areas in Africa $[9,13,14]$. When considering some of the major regional cities in Ethiopia, one can observe that Mekelle city has expanded with an $8 \%$ annual growth rate [15], Hawassa by $6 \%$ [16] and Adama city has expanded from 8.80 sq.km in 1984 to 51.3 sq.km in 2017 [17]. A national study conducted by Ethiopian Ministry of Urban Development, Housing and Construction (EMoUDH) and World Bank [18] and Central Statistical Agency (CSA) [19] also report how rapid urban expansion in Ethiopia has taken place. Furthermore, at this current growth rate, urban expansion and competition for land in Ethiopia will continue for the next few decades $[9,18]$, whilst rural areas are rapidly experiencing land ceiling and scarcity [20]. The effects and manifestations of the conflict between urban and rural areas are most visible in peri-urban areas, where the spatial expansion of built-ups and battles over land use are increasingly fought [21].

A peri-urban area in Ethiopia is characterized by the consistent expansion of informal settlements [22] and the ineffectiveness of formal land interventions. This is because most of the cities in Ethiopia have emerged as urban centers which grew without detailed land use plans [23], which moreover neglected the potential increase in informal settlements. This has resulted in a significant increase in illegal land occupation and unequal access to and distribution of land. These cause the proliferation of unmanageable land use and the emergence of unpredictable land use disputes, especially in the peri-urban areas [13,24-27]. On top of that, Ethiopia also has an uncontrolled population growth $[9,18]$ which aggravates the root causes for informality [28], forcing landholders to engage in informal transactions, which results in frequent land use changes [15-17]. On the administrative side, the land authorities are therefore unable to formulate information-based land use strategies [24,29] and mediate competing and conflicting interests [30] of the community, private investment sector, public investment sector, and other governmental and non-governmental development agencies. The effect of this is that the peri-urban areas are in continuous land use transformation and become highly vulnerable to disputes over land [20,25,31-33]. Obviously, such land use transformations and associated spatial expansion of cities affect the rural communities [20,34,35]. This apparently creates farmland scarcity that leads to food insecurity and thus it threatens the livelihoods of farmers [36].

As discussed above, urban expansion, land use change, and attributed peri-urban land use challenges are similar to those in other major regional capital cities in Ethiopia. Therefore, Bahir Dar, which is one of the four major regional cities, was selected purposively as a sample case study area. Different favorable factors are attributed to the expansion of the Bahir Dar city including topographical features, climatic conditions, water supply, accessibility, and its unique future for attracting tourists due to the existence of Lake Tana and Blue Nile river shores along with the city. Bahir Dar city administration has designated three main development corridors (i.e., west, east and south developmental corridors) considering the existence of Lake Tana in the north and Blue Nile River shores. The city is expanding from time to time towards these developmental corridors/peri-urban areas. This circumstance leads to the existence of frequent land use conflict with various degree and magnitude. Hence, this calls for a holistic understanding and analysis of the spatial patterns of built-ups, land use dynamics, and associated peri-urban land intervention processes in monitoring and controlling unwanted land use dynamics.

One of the potentials for such analysis lies in the effective uptake of newly available technologies and approaches. As indicated in the United Nations Committee of Experts on Global Geospatial Information Management (UN-GGIM) [37], alternative data sources and methodologies including geospatial information and Earth observation technologies play an indispensable role in measuring and 
monitoring the land use to address the 2030 agenda for sustainable development, which is advocated by the United Nations development programme. Over the past few decades, the development of geospatial technologies such as geographic information system (GIS) and remote sensing (RS) are increasingly serving as important tools for spatial pattern analysis [38-40]. The availability of information generated from Landsat imageries, aerial photographs, and other high-resolution imagery data has also significantly helped to understand the boundaries, patterns, dynamics, and trends of land use dynamics [41,42]. In addition, a socio-spatial analysis approach helps to integrate the spatial and social components of the land. This can be connected using geospatial technologies to provide a comprehensive analysis of the spatial dynamics of land use, land intervention and land-related decision-making processes. Hence, as it is discussed later in the empirical review section, this study is framed as a socio-spatial approach, consisting of a multi-dimensional relationship analysis of space and people (spatial and social dimensions related to land) rather than a separate and isolated analysis of each of the dimensions [43].

Different researchers, for example, Fenta et al. [15], Gashu and Gebre-Egziabher [16] and Haregeweyn et al. [36] have studied urban expansions and land use/land cover changes. However, the primary focus hereby was to identify and describe the location and volume of land cover changes connected to urban expansion. They did not explain why and how spatial patterns in changing built-ups are related to the changes in land use, and how the land intervention by land authorities is effective to curb and handle these processes. In other words, the previous contributors have loosely considered the relationships of the spatial patterns of built-ups, land use dynamics, and the response/effectiveness of the existing land intervention processes for monitoring and controlling unwanted land use dynamics. Methodologically, the previous contributors apply a spectral-based image analysis technique. This technique, as it is argued in different literature, gives relatively generalized land cover classes due to the mix of pixel information [37,38]. To address this quandary, it is necessary to evaluate the spatial patterns of built-ups and the dynamics of land uses using the integration of spectral and object-based image classification techniques. This technique is frequently applied to refine the quality of land use/land cover classes. Besides the quantification of land use changes, it needs a better understanding of how the existing land intervention frameworks and practices are responding to monitor unplanned spatial patterns of built-ups and attributed land use dynamics in different developmental corridors/peri-urban areas. Therefore, the objective of this paper is to evaluate the spatial patterns of changes in built-ups and land use, and to assess to what extent the existing peri-urban land intervention processes and land use decisions are effective in combating and controlling unwanted land use changes in the peri-urban areas of Bahir Dar city.

\section{Peri-Urban Land Use Dynamics}

\subsection{Concept and Implications}

Conceptually, land use dynamics manifest as socio-spatial changes which are haphazard, unpredictable and complex [44]. This is due to the fact that environmental, economic, and socio-cultural factors affect land tenure and land use behavior simultaneously yet not in a similar fashion or with similar effects [44-46]. Neither local communities nor local governments can properly oversee what occurs and how to properly influence and steer such dynamics in any preferred direction [47]. International Federation of Surveyors (FIG) made an effort to address the information gap on land use dynamics by improving the understanding of the relation between population growth and land occupation [48]. Urban populations are forecasted to increase roughly by 2.3 billion between the years 2014 and 2050 to reach $66 \%$ of the global population [49]. These will lead to the existence of both formal and informal urban expansions with consistent pressure on land use dynamics [50-53]. In this regard, Williamson et al. [12] and Don [11] estimate that one-third of urban dwellers in developing countries are living in informal and slum areas. This informality and expansion of urbanization have their own noticeable implications on land use dynamics, especially in peri-urban space. In other 
words, urbanization that happens outside of the formal planning process causes severe environmental, economic and societal problems [12,54]. These rapid growths of urbanization and land use changes in some parts of the world, basically developing countries, have created considerable governmental concerns and scholarly attention, as they are associated with economic growth, resource allocation, inequality, social unrest and sustainability $[6,7,55,56]$. This is because most land use development processes give less attention to spatial-based decision-making [57].

When we look at African trends, the continent's urban population has risen from 15\% in 1960 to $40 \%$ in 2010 and is projected to reach $60 \%$ by 2050 [58]. These imply that Africa will face uncontrolled peri-urban sprawl in the next decades [59,60]. When specifically zooming into East Africa, the level of urbanization is still the least in the world, but, the current rate of expansion in the region is the highest in the world [59]. This urban expansion will happen at the expense of agricultural lands which may be brought food insecurity to the local communities [61,62]. Besides, this trend of urbanization haphazardly growing massive challenges by which nearly three-quarters of Africa's urban residents reside in slums [12], is often unrecognized and un-serviced by their local governments [11]. This subsequently led to a deterioration of human settlements, an increase in poverty, depletion of natural resources, and of ecosystem services [63-65]. Additionally, when land transforms from rural to urban, different tenure and administrative systems start to apply which may lead to disputes, contestation, and in some cases, violence [66]. In the case of Ethiopia, the rural-urban conversion causes a change in tenure arrangement from a use right for unlimited time for rural land to a leasehold right in urban land. Simultaneously rural-urban conversion changes in terms of institutional arrangements from a rural land administration to an urban land administration system with distinct responsible authorities. Land conflict also increases with the increase in land scarcity and the ambiguity on which land law applies [67]. All these imply that the question of sustainable urban-rural land use dichotomy will remain a challenge, especially in countries where there exist isolated institutional and tenure modalities between rural and urban land. These challenges will continue unless immediate remedies have been taken through the uses of effective land use management systems/frameworks that can consider and respect the socio-cultural, environmental, political and economic dimensions of the land [68].

Ethiopia is also confronted with an alarmingly increasing peri-urban variation in land use dynamics. The informal land market, unfair access to formal land, and the lack of effective land use allocation are contributing to this variation in peri-urban land use dynamics in Ethiopia [34]. This creates massive stress and pressure on the livelihood of local communities and the sustainability of ecosystem services/environmental amenities [34]. In recent times, it was repeatedly observed that the Ethiopian urbanization process is taking place much faster than any other developing country [24]. According to the 2018 United Nations (UN) report [9], the urban growth rate in Ethiopia, which is $4.63 \%$, is higher compared to the average urban growth rate of Africa, which is $3.58 \%$, followed by Asia by $2.16 \%$. When we see the experiences of major regional cities in the past 10 years in Ethiopia, urban populations have increased by 80 to $106 \%$ [14,19] (see also Table 1). These rates have contributed to the existence of peri-urban land management problems [25].

Table 1. Urban population dynamics of major regional cities in Ethiopia in the last decade (2007-2017).

\begin{tabular}{cccc}
\hline \multirow{2}{*}{ Major Regional Cities } & \multicolumn{2}{c}{ Year } & Urban Population Change (\%) (2007-2017) \\
\cline { 2 - 4 } & $\mathbf{2 0 0 7}$ & $\mathbf{2 0 1 7}$ & \\
\hline Bahir Dar & 180,174 & 313,997 & 87.14 \\
\hline Hawassa & 157,879 & 335,598 & 106.28 \\
\hline Adama & 220,212 & 355,475 & 80.70 \\
\hline Mekelle & - & 358,529 & - \\
\hline \multicolumn{2}{c}{ Source: Statistical Agency of Ethiopia [14,19]. Urban population statistics. }
\end{tabular}




\subsection{Legislative Framework and Instruments of Land Interventions in Ethiopia}

The land-related legislative framework of Ethiopia comprises two separate lines of urban and rural land use frameworks and policies [21]. The urban land use policy promotes a lease system with fixed times [69,70], whereas, rural land administration and use proclamation guarantees free holding rights on the land [71,72]. This means that urban land settlers can acquire land only through the lease system, which is the main instrument for peri-urban land interventions. Landholders in urban areas have a right to transfer land through sale, mortgage, and exchange [69], but it is outlawed to rural landholders [73]. The land administration institutions are also divided into two broad sections, i.e., (1) urban land development and management section which is mandated and responsible for urban land administration, and (2) rural land administration and use section- mandated and responsible for rural land (see Figure 1). As clearly seen from Figure 1, there is a two-way communication within rural or urban tiers of land administration institutions. However, there is no formal horizontal hierarchy that can link urban and rural land administration institutions. This division has existed from Federal to regional level land administration units. When it comes to peri-urban areas, it is still vague to both types of administration systems on how they can properly intervene in peri-urban areas. In this regard, Wubie et al. [21] argued that isolation and sometimes overlapping of legislative and institutional frameworks create complexities for developing an agreed and comprehensive peri-urban land use plan and its intervention strategies. This inevitably affects the process of formal land use intervention and land-related decision making.

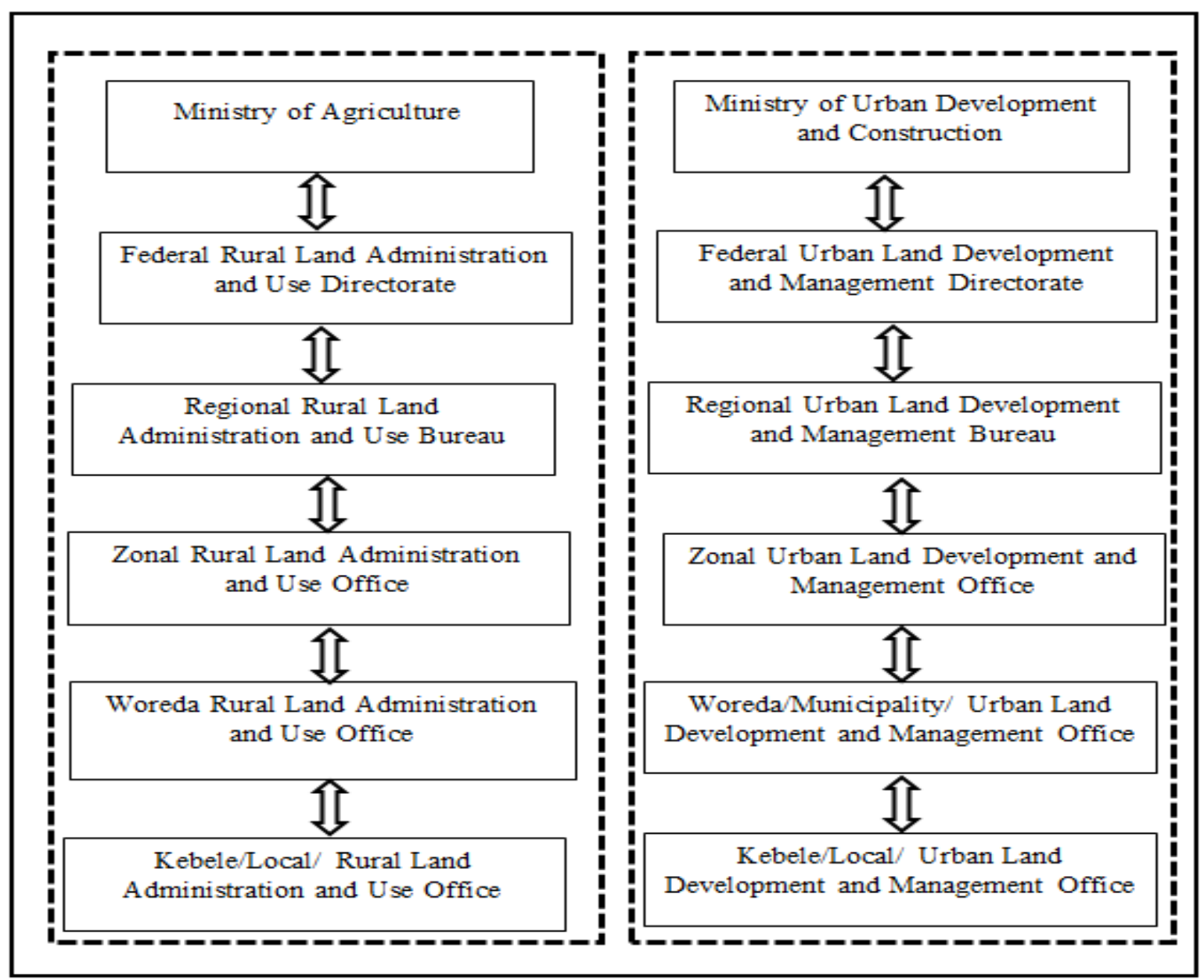

Figure 1. The existing isolated tiers of urban and rural land administration institutions. Source: Wubie et al. [21]. 


\section{Materials and Methods}

\subsection{Study Area}

Bahir Dar, a capital city of Amhara National Regional State (ANRS), was selected as a study area to study the spatial patterns of changes in built-ups and land use, and to assess to what extent the existing peri-urban land intervention processes and land use decisions are effective in combating and controlling unwanted land use changes in the peri-urban areas of the city. Geographically, Bahir Dar is located at the southern tip of Lake Tana-the source of the Blue Nile River, approximately $560 \mathrm{~km}$ northwest of Addis Ababa. The geographical map of the study city is indicated in Figure 2. Topographically, the central, northwest and southern parts of the city are relatively flat with a slope range from 0 to 3 degrees. Those areas are relatively vulnerable areas to frequent land use dynamics and attributed land use conflicts. The area has also undulating surfaces mostly in the northeast, and following Blue Nile River catchments, with the slope ranges from 8 to 39 degrees. Elevation of the area ranges from 1717 to 2010 m.a.s.l. The mean maximum and mean minimum annual temperatures are $28.3^{\circ} \mathrm{C}$ and $11.4^{\circ} \mathrm{C}$, respectively. Summer season (June, July and August) is regularly rainy season while rainfall becomes almost non-existent in December, January, February and March [74]. According to the Food and Agriculture Organization (FAO) soil classification system, Vertisols, Luvisols and Nitosols are the three major types of soils in the Bahir Dar area [75].

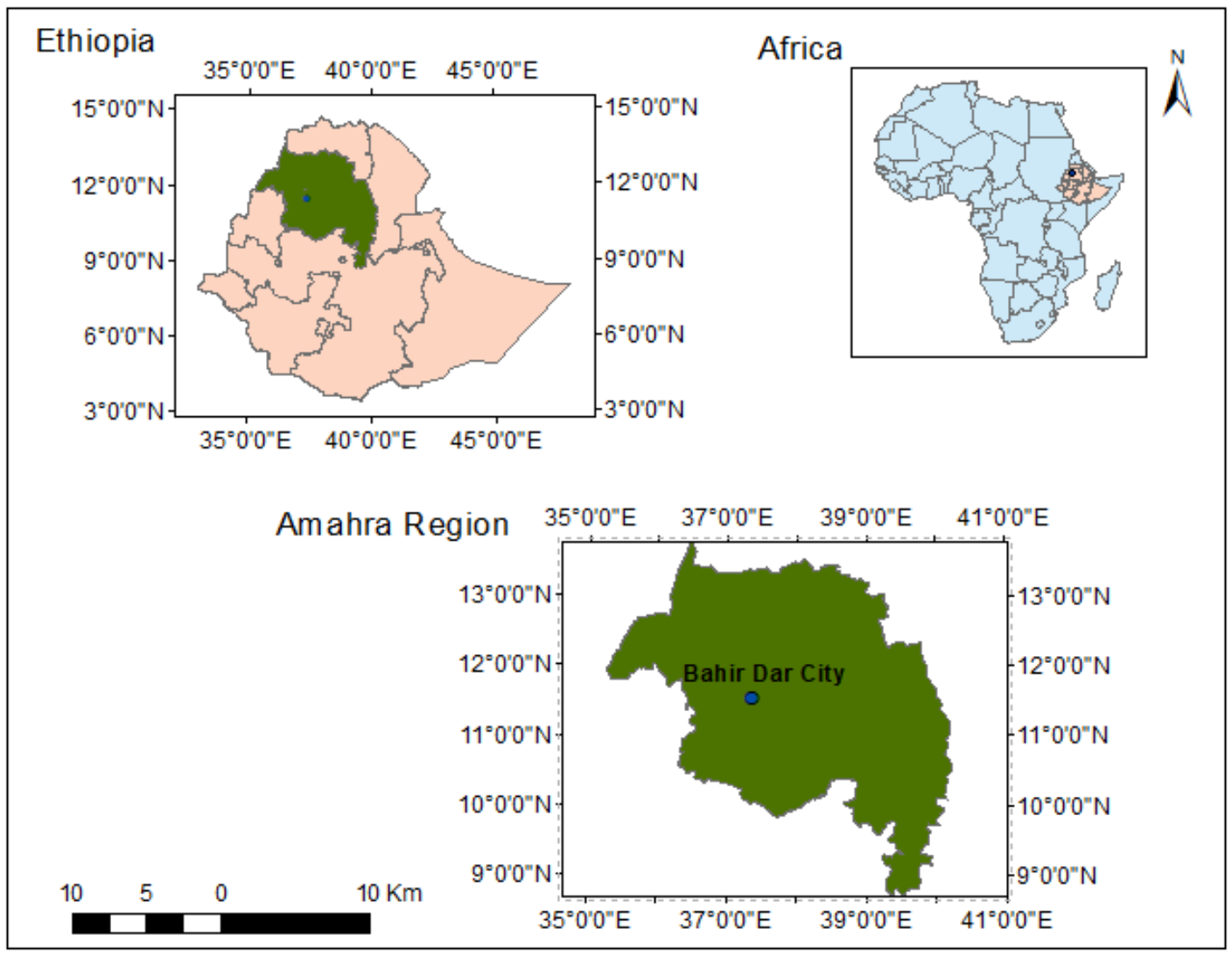

Figure 2. Location of the case study city.

As discussed above, the population of Bahir Dar city is increasing from time to time. Within the last 10 years, urban population has increased from 180,174 in 2007 to 313,997 in 2017 [14,19] (see also Table 1 above). Similar to other Ethiopian areas, agriculture, industry and service are the major economic activities in Bahir Dar and the surrounding areas. When we see the last 10 years, the contribution of agriculture to the national gross domestic product (GDP) is decreasing through time, whereas industry and service sector is increasing ([76]) (see Figure 3). All these imply that urban function, industry and 
service sectors are expanding towards rural areas. This is the case in Bahir Dar which is expanding from time to time towards the different developmental corridors/peri-urban areas with unpredicted spatial patterns of built-ups and land use changes. This circumstance leads to the existence of frequent land use conflict in every developmental corridor with various degree and magnitude. Hence, this calls for a holistic understanding of the spatial patterns of built-ups, land use dynamics, and associated peri-urban land intervention processes in monitoring and controlling unwanted land use dynamics. Taking into account the aforementioned concerns, this study primarily focused on evaluating the spatial patterns of changes in built-ups and land use in the peri-urban areas of Bahir Dar city. It also evaluates the extent to which the existing peri-urban land intervention processes and land use decisions are effective in combating and controlling unwanted land use changes.

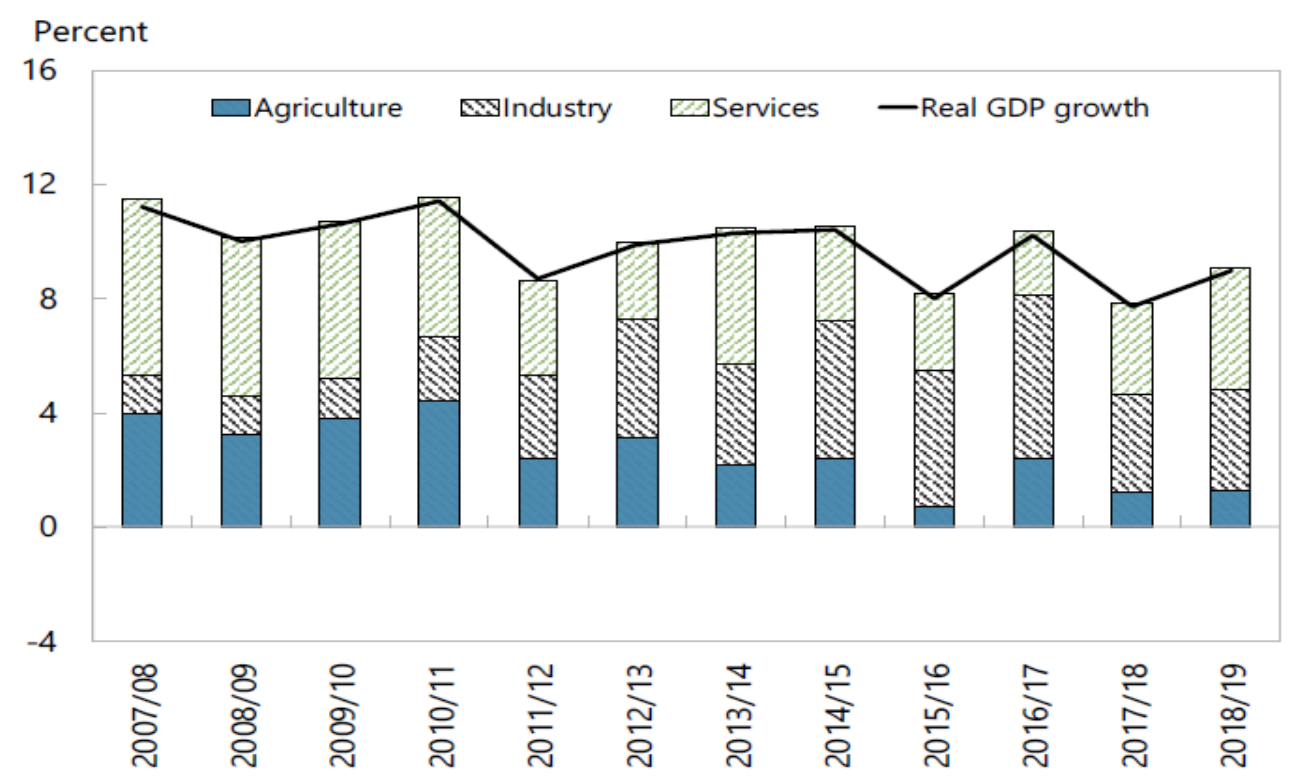

Figure 3. Ethiopian real GDP growth and contribution by sector from 2007/08 to 2018/19. Source: IMF [76], International Monetary Fund Country Report No. 20/29 of the Federal Democratic Republic of Ethiopia.

\subsection{Research Approach and Design}

The goal of this study is to evaluate the spatial patterns of changes in built-ups and land use, and to assess to what extent the existing peri-urban land intervention processes and land use decisions are effective in combating and controlling unwanted land use changes. Hence, the data collection and analysis relied on a socio-spatial approach whereby multi-dimensional spatial changes were taken into account in relation to the changing behavior of people [43,77]. This approach includes the collection of both spatial and socio-economic data simultaneously in order to enable a comprehensive analysis of the spatial patterns of built-ups, land use dynamics, and the process of land interventions. We considered both landholders (informal and formal) and government as acting persons because their interactions amongst each other constitute the emerging land use dynamics. This helps to know specific actions on how, why and where actors convert land and take decisions on land. To answer such questions, we selected Bahir Dar city as a study area because of its rapid expansion, the availability of data and access to the government and local communities is relatively convenient to collect firsthand data. Regarding the time frame, we were interested in the period from 1993 to 2020. The dates were selected based on the basic remarks and changes in urban and rural land intervention frameworks. The 1993 first urban land lease system is a basic turning point in peri-urban land intervention processes in the country. We used images and documents related to land uses and land use decisions from land administration institutions. 


\subsection{Unit of Analysis and Sampling Techniques}

The units of analysis in this study constitute: patterns of built-ups (visible and analyzable through satellite imageries and geographic data), land use/land cover (visible and analyzable through satellite imageries), land use intervention process (expressed from governmental documents and collectable through a questionnaire survey, interviews and focus group discussions (FGDs)), land use policy (observable from government documents, and its implementation/effectiveness is collectable through interviews and surveys) and population (visible and observable through statistical data). Though the spatial expansion of built-ups, land use dynamics and peri-urban land use intervention problems are a common phenomenon in Ethiopia, Bahir Dar city and its periphery was selected purposively as a study site. Within this area, we consider that there exists land use dynamics and unpredictable spatial patterns of built-ups, whereby the boundary of units of analysis and influence of national and local factors is unclear. Hence, we argue that we conduct an analysis of the spatial patterns of built-ups and land use dynamics with multiple units of analysis. The households living in peri-urban areas were the target total population of the study. However, due to the rapid dynamicity of the peri-urban population, informality, and the implicit dichotomy of the urban and rural population, the exact total number of the population who are living in the peri-urban area is not exactly known. Hence, the sample size was determined using a proportional sample size determination formula (considering high population, high population dynamicity and high variability in the acceptance of specific land use management framework) recommended by Cochran [78], Yamane [79] and Israel [80] which calculated as no $=\frac{Z^{2} p q}{e^{2}}=\frac{Z^{2} p(1-p)}{e^{2}}$, where no is the sample size, $Z$ standard score at a specified confidence interval, $\mathrm{e}$ is the desired level of precision (the margin of error), $\mathrm{p}$ is the estimated proportion of an attribute that is present in the population, and q is 1-p. The proportion of the population (p) can be known from the previous research sources; if not, it is possible to use 0.5 (maximum variability). Thus, the sample size of the study was calculated with the assumptions of $95 \%$ confidence level which gives a $\mathrm{Z}$ value of 1.96 from the $\mathrm{Z}$ table, $5 \%$ margin of error and $\mathrm{p}$ is 0.5 (maximum variability). Therefore, based on the above assumption and formula, the total number of sample sizes is $\frac{1.96^{2} \times 0.5(1-0.5)}{0.05^{2}}$ which equals 384 sample households. Sample household respondents were selected using a simple random sampling technique.

\subsection{Methods of Data Collection}

\subsubsection{Socio-Economic Data}

Primary data related to the impact and effectiveness of the existing peri-urban land use intervention process, land use policy, land use changes and decisions related to land were collected using questionnaires, focus group discussions (FGDs) and interviews. An FGD and interview were conducted to complement the results in the questionnaire and spatial data analysis. The differences in response were validated by data triangulation techniques. The aim and the procedures for each method are discussed as follows:

Focus Group Discussion (FGD)—was held (to complement the results in the questionnaire analysis) with selected local communities and land administration operational staff/land administration authorities. The FGD was held following the formal protocol by two moderators-the main moderator and assistant moderator [81,82]. The main moderator introduced the topic, the aim of the discussion, and how the responses would be kept confidential. The moderator directed the whole FGD process by briefing and intervening on FGD leading questions. Additionally, the main moderator took very brief notes. The assistant moderator mainly took notes and recording the response using an audio recording. The audio was translated to texts and summarized by cross-checking the note taken by the assistant moderator and main moderator. The response was validated by sending the summary of the discussion to the participants. 
Interviews-the purpose of the interview was to view the perceptions, experiences, and recommendations of land and land-related authorities towards peri-urban land use intervention processes. A semi-structured interview questionnaire was prepared and interviews were conducted in various categories with selected land administration authorities (at the federal, regional, and local level) who are directly or indirectly playing a crucial role in promoting specific land use intervention alternatives and related policy decision making. Interview responses were recorded using an audio recorder and translated. The key informant from each actor was interviewed until the data were saturated.

Questionnaire-both open and closed-ended questionnaires were developed, and firsthand information related to the impact and effectiveness of the existing peri-urban land use intervention process; land use policy, land use changes and decisions related to land were collected from sample household respondents. Meanwhile, supportive secondary data-largely descriptive data-were collected from federal and regional land administration institutions. In addition, other supportive documents and research outputs related to the study were reviewed from different land management/governance/science journals, articles, and books.

\subsubsection{Spatial Data}

Spatial data including Thematic Mapper (TM), Enhanced Thematic Mapper Plus (ETM+), Landsat8, and Sentinel imageries acquired in 1993, 2001, 2011 and 2020 were downloaded from the United State Geological Survey (USGS) earth explorer (https://earthexplorer.usgs.gov/) portal. The dates were selected purposively based on the basic remarks and changes in urban and rural land intervention frameworks. The 1993 first urban land lease system is a basic turning point in peri-urban land intervention processes in the country. The other dates were selected purposely considering time intervals and the availability of data. In addition to Landsat imageries, other high-resolution imageries like an aerial photo, SPOT image, and Orthophoto were collected from the Ethiopian Geospatial Information Institute and Bahir Dar city administration. These high-resolution imageries were used to further improve and refine the different years of land use/land cover types using object-based image classification techniques.

Flaws or distortions such as radiometric distortions, geometric distortion, and atmospheric effect of Landsat imageries [83] were corrected by applying pre-processing techniques including radiometric correction, geometric correction and noise removal or atmospheric corrections. Image enhancement including resolution merge, contrast stretching and histogram equalization techniques were also applied to increase the visibility and interpretability of images. Image enhancement helps to expand the narrow range of brightness values typically present in an output image over a wider range of gray values [83]. Then, image classification or land use/land cover classes were identified using supervised/pixel-based/image classification techniques. Image classification is the process of creating thematic maps from satellite imagery [84]. A thematic map is an information representation of an image that shows the spatial distribution of a particular theme [83]. The number and types of land use/land cover classes in a particular area may vary depending on the purpose of classification and the physical characteristics of the area; hence, the numbers of land use/land classes in this study were determined based on the purpose, function and the major land use/land cover types of the study area following the recommendation of FAO [85] and Jansen [86]. We used the official boundary shapefile of the city administration for the designation of inner-city and the three developmental corridors/peri-urban areas of Bahir Dar. The northern part of the city is not designated as a development corridor because of the existence of Lake Tana. Hence, the amounts and locations of the spatial expansion of built-ups and land use dynamics were reported using the existing spatial extents of each developmental corridor. Within these areal extents, six land use/land cover classes, namely, built-ups, farmlands, vegetation, open and green areas, wetlands, and water bodies are identified based on FAO-AFRICOVER land cover classification system [85], which is adapted to the African region context (see the description of land use/land cover classes in Table 2). By assigning the signature value of the major land use/land 
cover classes, the maximum likelihood classifier algorithm, and spatial merging algorithm were applied to obtain a more homogeneous appearance of the individual classes [84]. The maximum likelihood algorithm is an efficient statistical approach to classify land use classes from satellite imageries based on pixels values of the sample training points [84]. In the classification process, the spatial merging algorithm helps to refine and convert the pixel-level classification results into contiguous maps [87]. In addition, object-based image classification was applied further to improve and refine the land use/land cover classes that are computed through pixel-based image classification techniques. This is computed using the help of high-resolution imageries to obtain detail and accurate land use/land cover classes. The classification accuracy was tested using confusion matrix following the recommendation [88]. A total of 108 ground reference points were collected to evaluate the accuracy of the classification. Accordingly, $90.74 \%$ of overall classification accuracy was obtained for the year 2020 image classification.

Table 2. Type and description of land use/land cover classes.

\begin{tabular}{|c|c|}
\hline Land Use/Land Cover Classes & Description \\
\hline Built-ups & $\begin{array}{l}\text { Areas that have an artificial cover/uses resulting from human activities } \\
\text { such as constructions of all kind, urban fabric, industrial, commercial, } \\
\text { residential, transportation units and other construction sites }\end{array}$ \\
\hline Farmlands & $\begin{array}{l}\text { Areas that are used for crop cultivation and other heterogeneous } \\
\text { agricultural/farming areas }\end{array}$ \\
\hline Vegetation & $\begin{array}{l}\text { Areas that have a vegetative cover consisting of woody, trees, shrub or } \\
\text { herbaceous, sparse forest and vegetation association }\end{array}$ \\
\hline Open and green areas & $\begin{array}{l}\text { All open spaces with little or sparse vegetation, including artificially } \\
\text { vegetated green areas }\end{array}$ \\
\hline Wetlands & Waterlogged ecosystem/areas either permanently or seasonally \\
\hline water bodies & Areas that are covered by lakes, ponds, and rivers \\
\hline
\end{tabular}

\subsection{Data Analysis}

Remote sensing image analysis software (ERDAS IMAGINE 2015), geographic information systems (GISs) and spatial pattern analysis software were used to compute the spatial expansion, trend and patterns of built-ups and land use dynamics. Hence, spatial data were processed and computed by using a geo-statistical algorithm. Socio-economic data were quantitatively analyzed using descriptive statistics to measure, describe and summarize the behavior of the sample data. The validity and consistency of the data were tested using Cronbach's alpha reliability coefficient following the recommendation of Rovai et al. [89]. Cronbach's alpha coefficient measures the internal consistency and reliability of items based on the mean inter-item relation of an instrument [89]. As recommended by Rovai et al. [89], Cronbach's alpha reliability test greater than or equal to 0.7 is accepted as high reliability. The data collected through a closed-ended questionnaire were analyzed using a statistical package for the social science (SPSS) software; whereas, responses from open-ended questionnaires, interviews and FGDs were analyzed and interpreted qualitatively in a content-wise. The general methodological framework of the study is indicated in Figure 4. 




Figure 4. Methodological framework.

\section{Result and Discussions}

\subsection{Patterns and Spatial Expansion of Built-Up Areas (1993 to 2020)}

The spatial expansion and patterns of built-up areas in Bahir Dar city and its periphery were computed from Landsat and high-resolution imageries using the integration of spectral and object-based image classification techniques (Figure 5). The analysis was computed for the last three decades (1993-2020) following the basic changes in urban and rural land use intervention frameworks-the 1993 first urban land lease system is a basic turning point in peri-urban land intervention processes in Ethiopia. As presented in Table 3, built-up areas were expanded by $260.7 \mathrm{ha}, 640$ ha, and 234.2 ha of land from 1993 to 2001, 2001 to 2011, and 2011 to 2020, respectively. A total of 3564.26 ha of land were converted to built-up areas from 1993 to 2020 with $6.73 \%$ annual average rates of expansions. From 1993 to 2011, most of the spatial expansions of built-ups existed within the current inner-city boundary (Figure 5A-C). After 2011 onwards, however, built-ups are extremely expanding towards the peri-urban areas (see Figure 5D). These expansions are happening in three main development corridors/peri-urban areas-towards west, east, and south development corridors (see the development corridors in Figure 5). Of the three developmental corridors, most of the spatial expansions of built-ups (marked in red colors in the maps) are observed in the west and east developmental corridors which account for 632.2 and 751.1 ha of land from 2011 to 2020, respectively. Meanwhile, highly irregular patterns of built-up expansions were observed towards the south development corridors, and following the main roads in the west and east development corridors, especially irregularity increases away from the main roads due to the presence of illegal settlers by hiding themselves in non-visible areas. The results here depict that processes of built-up expansion do not only determine the horizontal urban expansion but also they determine the nature of people-to-land relationships, which involves both formal and informal processes of built-up expansion. The variation in the patterns and spatial expansions of built-ups is connected with the existence of main roads and favorable topography of the 
area. The expansion of built-ups following the river is somehow insignificant due to the restrictions for green areas. This is particularly the case outside of the inner city. From this, it is also possible to argue that the expansions of built-ups outside of the inner city boundary (especially when there are open spaces within the inner city) are directly connected with the inefficiencies of the land use management and land intervention processes. This creates haphazard, disputed, and unregulated land use systems in peri-urban areas of Bahir Dar. Furthermore, spatial results effectively demonstrate the spatial trends of built-ups. With the current annual average rates of expansions, the results in Figure 5 predict that a total of 3960.2 ha of land will be converted to built-up areas by 2050 .

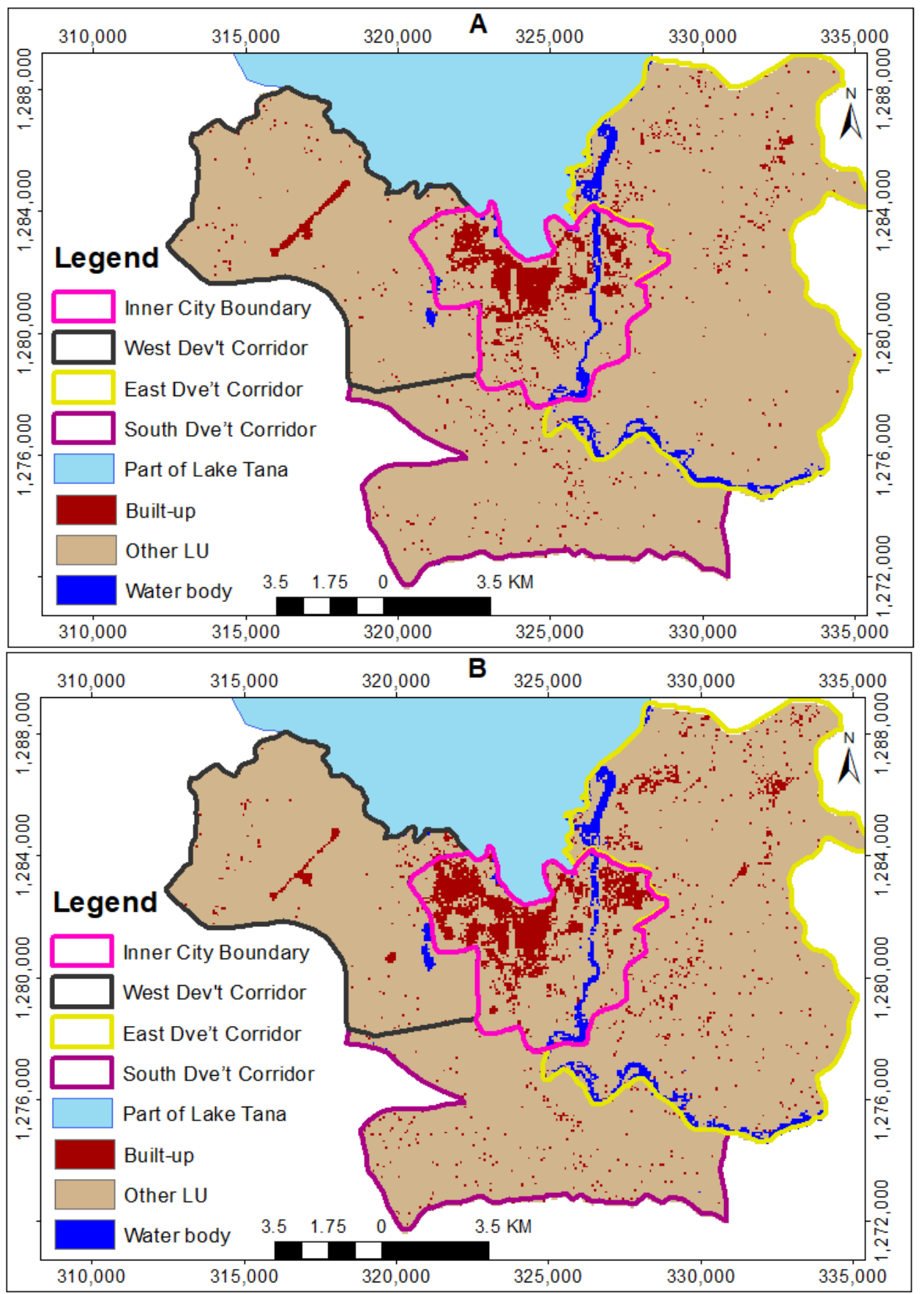

Figure 5. Cont. 




Figure 5. The spatial patterns and expansion of built-ups in each developmental corridor/peri-urban area; (A) (1993), (B) (2001), (C) (2011) and (D) (2020). 
Table 3. The spatial expansion of built-ups towards each developmental corridor/peri-urban area.

\begin{tabular}{ccccc}
\hline \multirow{2}{*}{ Developmental Corridors/Peri-Urban Areas } & \multicolumn{3}{c}{ Spatial Expansion of Built-Up Areas in ha } \\
\cline { 2 - 5 } & 1993-2001 & $\mathbf{2 0 0 1 - 2 0 1 1}$ & $\mathbf{2 0 1 1 - 2 0 2 0}$ & $\mathbf{1 9 9 3 - 2 0 2 0}$ \\
\hline Within the inner city boundary & 260.7 & 640 & 234.2 & 1134.9 \\
\hline Towards West development corridor & 16 & 297.5 & 632.2 & 945.7 \\
\hline Towards East development corridor & 155 & 258.9 & 751.1 & 1165.1 \\
\hline Towards South development corridor & 21.5 & 32 & 265 & 318.5 \\
\hline Total & 453.2 & 1228.4 & 1882.5 & 3564.2 \\
\hline Average annual expansion rate $(\%)$ & 5.01 & 7.75 & 7.44 & 6.73 \\
\hline
\end{tabular}

The result of this study supports other related studies conducted in major regional cities in Ethiopia and other African countries. For instance, Fenta et al. [15] and Gashu and Gebre-Egziabher [16] indicated the presence of a high rate of urban expansion with $8 \%$ and $6 \%$ in Mekelle and Hawassa cities, respectively. This high rate of urban expansion is highly connected to the existence of informal and irregular patterns of built-ups following, and some times away from the main roads [77]. Another study conducted by Manikandan [17] also indicated that Adama city has expanded from 8.80 sq.km in 1984 to 51.3 sq.km in 2017. In addition, other studies conducted in different African countries, for instance, in Cameroon by Gwan and Kimengsi [62], Malawi by Mawenda et al. [90], Ghana by Karg et al. [60] and Akubia et al. [65] and Ethiopia by Haregeweyn et al. [36] also indicated the presence of a high rate of urban expansion in major regional cities. However, the average rate of expansion of built-up areas in the study area was found much higher than the national average expansion rate, i.e., nearly 5\% as it is reported by the EMoUDHC [13], United Nations [9] and CSA [14,19]. This implies that the spatial expansions of built-ups in major regional cities are higher in Ethiopia, and this creates considerable land use management challenges, especially in peri-urban areas of the major regional cities in the country. As it is also generally argued by Banzhaf et al. [50], the spatial expansions of built-ups could create consistent pressure on land use dynamics.

\subsection{The Spatial Dynamics of Peri-Urban Land}

The spatial dynamics of Bahir Dar city and its peri-urban areas have been analyzed from 1993 to 2020 (see Figure 6). The analysis was computed for the last three decades (1993-2020). As clearly shown in Figure 6, six land use/land cover classes, namely, built-ups, farmlands, vegetation, open and green areas, wetlands, and water bodies are identified for the years 1993, 2001, 2011 and 2020. Substantial LULC changes have been observed in the last three decades. Built-up areas have drastically increased from 1993 to 2020 (see the red marked colors in Figure 6). As clearly presented in Table 4, 453.2 ha of land was converted to built-up areas from 1993 to 2001; whereas farmland, vegetation, open area, and water bodies were decreased by 247.9, 112.2, 95.8 and 8.1 ha of land in the same year, respectively. From 2001 to 2011, built-up areas were increased by 1228.4 ha of land while farmlands, vegetation, open and green areas, and wetlands were drastically decreased by 495.3, 392.4, 311.1, and 19.2 ha of land, respectively. Similarly, built-ups areas were increased by 1882.5 ha of land while farmlands, vegetation, open and green areas, wetlands, and water bodies were decreased by 848.7, $544.4,319.2,93.4$, and 76.8 ha from 2011 to 2020 , respectively. 


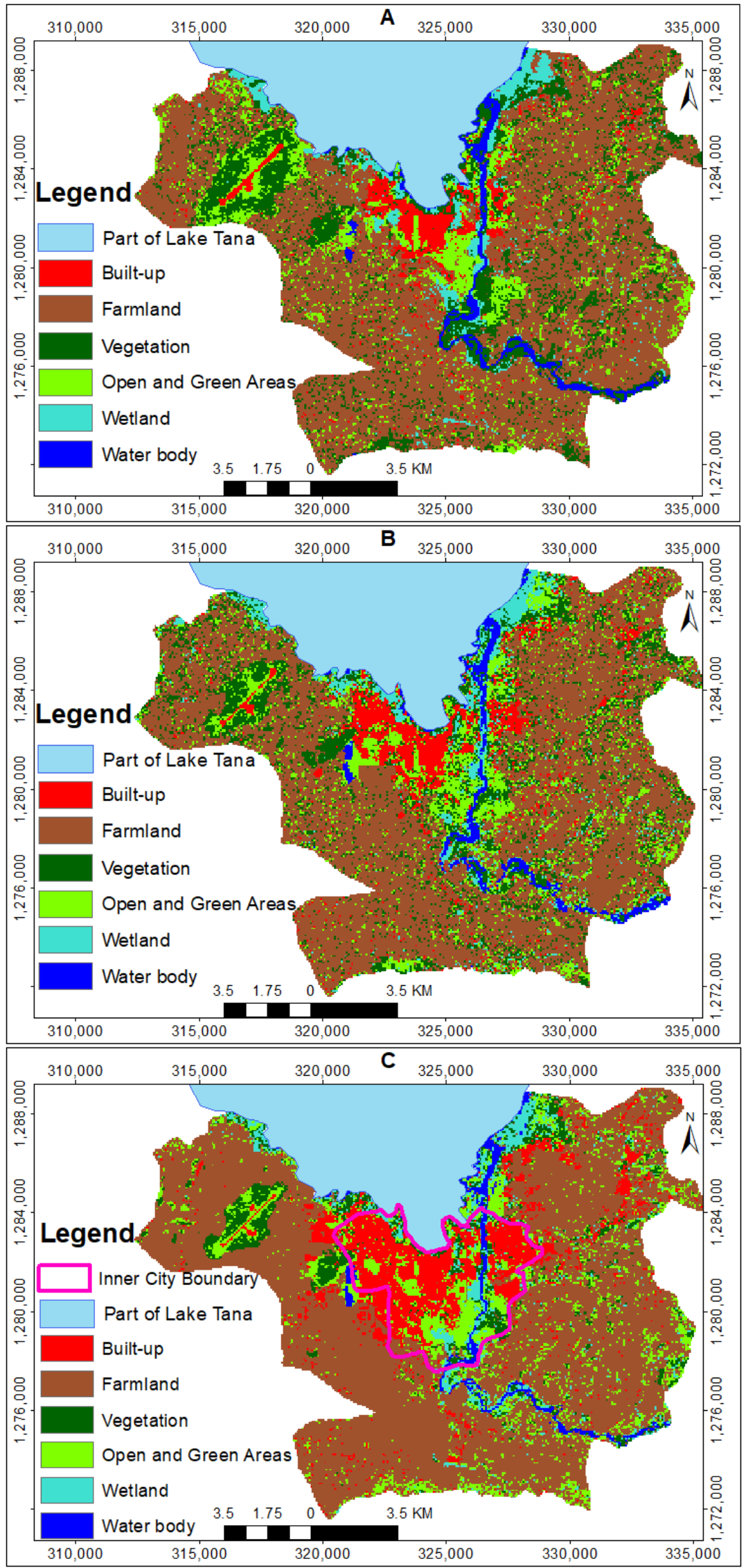

Figure 6. Cont. 


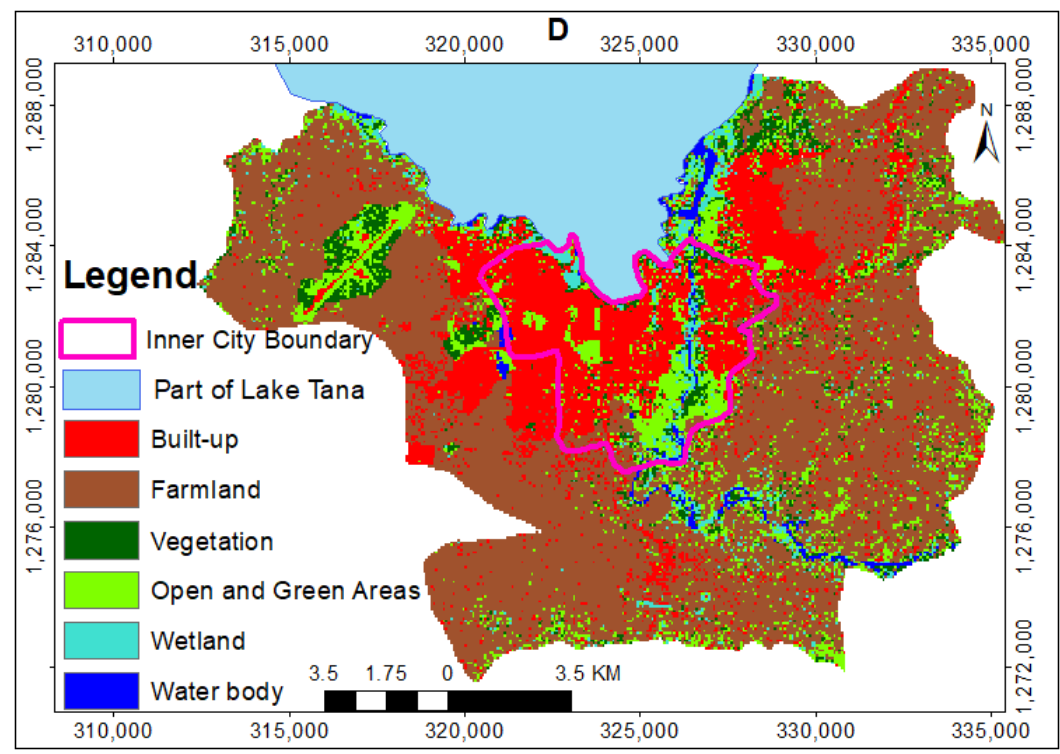

Figure 6. Land use/land cover (LULC) map of Bahir Dar and its peri-urban areas/developmental corridors; (A) (1993), (B) (2001), (C) (2011) and (D) (2020).

Table 4. The spatial dynamics of Bahir Dar city and its peri-urban areas.

\begin{tabular}{ccccc}
\hline \multirow{2}{*}{ LULC } & \multicolumn{4}{c}{ Spatial Change in ha } \\
\cline { 2 - 5 } & $\mathbf{1 9 9 3 - 2 0 0 1}$ & $\mathbf{2 0 0 1 - 2 0 1 1}$ & $\mathbf{2 0 1 1 - 2 0 2 0}$ & $\mathbf{1 9 9 3 - 2 0 2 0}$ \\
\hline Built-ups & 453.2 & 1228.4 & 1882.5 & 3564.2 \\
\hline Farmland & -247.9 & -495.3 & -848.7 & -1591.9 \\
\hline Vegetation & -112.2 & -392.4 & -544.4 & -1049 \\
\hline Open and green areas & -95.8 & -311.1 & -319.2 & -726 \\
\hline Wetlands & 10.8 & -19.2 & -93.4 & -101.8 \\
\hline Water body & -8.1 & -10.4 & -76.8 & -95.5 \\
\hline
\end{tabular}

For the last three decades, 3564.2 ha of land was converted to built-up areas with both regular and irregular patterns; highly regular patterns of built-up expansions were observed towards the south development corridors, and following the main roads in west and east development corridors (see the discussion in Section 4.1). This implies that the current land intervention processes contributed to the horizontal expansion of built-ups at the expense of other land uses. Such trends of the spatial expansions of built-ups create consistent pressure on land use dynamics and deterioration of the ecosystem. The results of land use dynamics here portray that the contribution of the informal land use intervention is high for the dynamic and high rate of conversion of peri-urban land uses. This context supports contemporary studies conducted in Ethiopia and other developing countries. For instance, a study conducted by Wubneh [20] indicated that rural land uses in Ethiopia are rapidly overtaken by the existing urbanization processes. Other studies conducted in Nigeria [51], Ghana by Karg et al. [60] and Akubia et al. [65], Cameroon by Gwan and Kimengsi [62], Malawi by Mawenda et al. [90] and Chain by Robinson and Song [53], Tian and Wang [56] and Tian [91] indicate the existence of massive land use dynamics that highly affect the livelihoods of local communities and the sustainability of ecosystem services. The discussion so far, both in Sections 4.1 and 4.2, indicates a high rate of horizontal expansion of built-ups and attributed land use dynamics, and this creates problems on the local communities, governments and the ecology of local environments. These contexts are also evidenced from the socio-economic data analysis as the social analysis supports understanding of the processes of land use interventions, which can be considered as driving factors for the observed land use dynamics 
in the study area. Here, it can be noted that the social and spatial dimensions of the peri-urban land have a cause and effect relationship where the social dimension triggers interventions to effect the spatial dimension and it is well observed in the form of land use dynamics (Section 4.3 below).

\subsection{Land Intervention Process and Its Effectiveness for Governing Land Use Dynamics}

Empirical data on processes of land use interventions were obtained from the sample household respondent using a questionnaire survey to assess whether there is contextual and clear land use policy (LUP)/legal framework enacted for land use intervention/allocation or not. Out of the total of 384 sample household respondents, 348 sample respondents correctly completed and returned the questionnaire. Cronbach's alpha reliability coefficient for interrelated items was 0.843 , which is accepted as high reliability [89]. Of the total respondents, $27 \%$ of the sample household respondents indicated the availability of contextual and clear land use policy/legal framework enacted for peri-urban land use intervention process. Of the respondents who indicated the availability of clear land use policy, $36 \%$ of the respondents reported that the policy is well integrated and implemented among the different levels of land administration institutions. More than half (57\%) of the sampled household respondents, however, reported that the policy lacks clear integration and proper implementation among different levels of land administration institutions. The remaining $7 \%$ of the respondents were not in a position to argue on the integration level of land use policy among the different land administration institutions. Regarding the transparency of LUP/legal frameworks, only $21 \%$ of the sample household respondents highlighted that the existing land intervention framework is transparent and available.

Similarly, FGD participants and key informants were forwarded different views regarding the availability of contextual land use policy enacted for regulating and monitoring land intervention processes. Among the discussants, four operational staff FGD discussants outlined the presence of land intervention policies by referring to the 2011 urban land lease policy [69] and the 2005 rural land administration and use framework [71] as an example. Three discussants claimed the existence of fragmented policies and frameworks, but they outlined the lack of comprehensive policy that is enacted for peri-urban land interventions. Some of the other three discussants disclosed the lack/absence of comprehensive and appropriate policy regarding land, land use, and land use interventions. Likewise, one of the key informants replied that "the country does not have a clear and visible land use policy and land use intervention framework prepared by the government instead there are fragmented laws and frameworks in rural and urban sectors". In addition, other key informants mentioned that "the land administration institution uses local regulations, directives or frameworks, and these frameworks are highly subjective to changes in different time and space". Another respondent replied that "peri-urban in Ethiopia is one of the gray areas in policy as well as in practices and it is a highly missed up and continuously exploited area by different actors' without a robust conflict redress mechanism". Out of 10 key-informants, seven respondents have reported very similar ideas to the above-mentioned views and arguments. This implies that the legal frameworks enacted for peri-urban interventions in Ethiopia are fragmented, inconsistent, and subjected to changes from time to time.

Both the empirical data analysis and responses from FGD and key informants indicated that the existing peri-urban land intervention policy/legal frameworks are fragmented and lack transparency. The policies are fragmented in a way that both urban and rural land administration institutions have their own land use policies. This can be elaborated by considering the existing urban and rural land use policies. The urban land use policy promotes a lease system with fixed time $[69,70]$, whereas rural land administration and use proclamation guaranteed free holding right on the land [71,72]. In addition, landholders in urban areas have a right to transfer land through sale, mortgage, and exchange [69], but it is outlawed to rural landholders [73]. In both of the legal frameworks, however, nothing is said (left vacuum) about peri-urban areas and it is still vague to manage the land properly [21]. This indicated that the working legal frameworks for peri-urban land interventions are fragmented, overlapping, and lack transparency since the land intervention process considers both urban and rural land use policies. From this, it is possible to argue that the existing peri-urban land intervention 
frameworks of Ethiopia are not congruent and appropriate enough to sustainably manage the rapidly expanding informal built-ups and unwanted land use dynamics. These contexts were also evidenced in the spatial data analysis (see Figure 5, Section 4.1 and Figure 6, Section 4.2).

Concerning the effectiveness of peri-urban land intervention, the empirical data analysis result, which is $57 \%$ of the sample household responses, indicated that the existing land intervention process remains behind to be effective and contribute towards governing the rate and extent of unwanted land use dynamics in the peri-urban areas of the city (see Table 5). Only $4 \%$ of the sample household respondents perceived that the existing land intervention framework is effective in governing unwanted land use dynamics. Nearly one-third $(29 \%)$ and $1 \%$ of the respondents rated the effectiveness of the framework as moderately effective and extremely effective, respectively. The remaining $9 \%$ of the respondents were undecided to rate the effectiveness of the existing land use intervention framework. Similarly, $59 \%$ of the respondents perceived that the existing framework is ineffective in reducing peri-urban land use conflict. Very few $(5 \%)$ of the respondents reported that the existing land use framework is effective in governing the rate and extents of peri-urban land use conflicts. In this regard, one of the key informants reported that "the land administration institution uses local regulations and directives for peri-urban land intervention processes, which are highly subjective to changes across time and space and thus, the effectiveness of the framework is highly depending on the effectiveness of the local management/administrative units". Other key informants outlined that "the peri-urban space is poorly represented both in a legal framework and institutional arrangements; there might be a frequent change of directives to secure some group's interest". The remaining key informants also reported very similarly to this argument. This implies that the existing land intervention processes lack effectiveness in governing unwanted land use dynamics (see also the rate of land use dynamics in Figure 6).

Table 5. Effectiveness of the existing LU framework for governing the rate and extents of land use dynamics and land use conflicts.

\begin{tabular}{cccccc}
\hline Response & $\begin{array}{c}\text { How Do You Evaluate the } \\
\text { Effectiveness of the Existing LUP } \\
\text { or the Actual Land Intervention } \\
\text { Practice for Governing the Rate } \\
\text { and Extent of Unwanted Land } \\
\text { Use Dynamics in Peri-Urban } \\
\text { Areas of the City? (Valid } \boldsymbol{n}=348)\end{array}$ & $\begin{array}{c}\text { How Do You Evaluate the } \\
\text { Effectiveness of the Existing LUP } \\
\text { or Actual Land Intervention } \\
\text { Practice for Reducing the Rate } \\
\text { and Extents of Peri-Urban Land } \\
\text { Use Conflict? (Valid } \boldsymbol{n}=\text { 348) }\end{array}$ \\
\cline { 2 - 5 } Valid & Frequency & Percentage & Frequency & Percentage \\
\hline Highly effective & 5 & 1.4 & 5 & 1.4 \\
\hline Effective & 14 & 4.0 & 17 & 4.9 \\
\hline Moderately effective & 100 & 28.7 & 96 & 27.6 \\
\hline Ineffective & 199 & 57.2 & 205 & 58.9 \\
\hline Undecided & 30 & 8.6 & 25 & 7.2 \\
\hline Total & 348 & 100.0 & 348 & 100.0 \\
\hline
\end{tabular}

The respondents further reported that the existing land intervention practices lack effectiveness for respecting and maintaining the desirable land intervention indicators (see Figure 7). In this regard, the majority of the sample household respondents perceived that the existing land intervention processes are far from being effective. Very few (less than 10\%) of the sample household respondents perceived that the existing land intervention practice is effective for addressing contemporary land intervention indicators. This means that the existing land intervention processes lack effectiveness in considering the socio-cultural, economic, environmental, and political dimensions of the land (see Figure 7). 


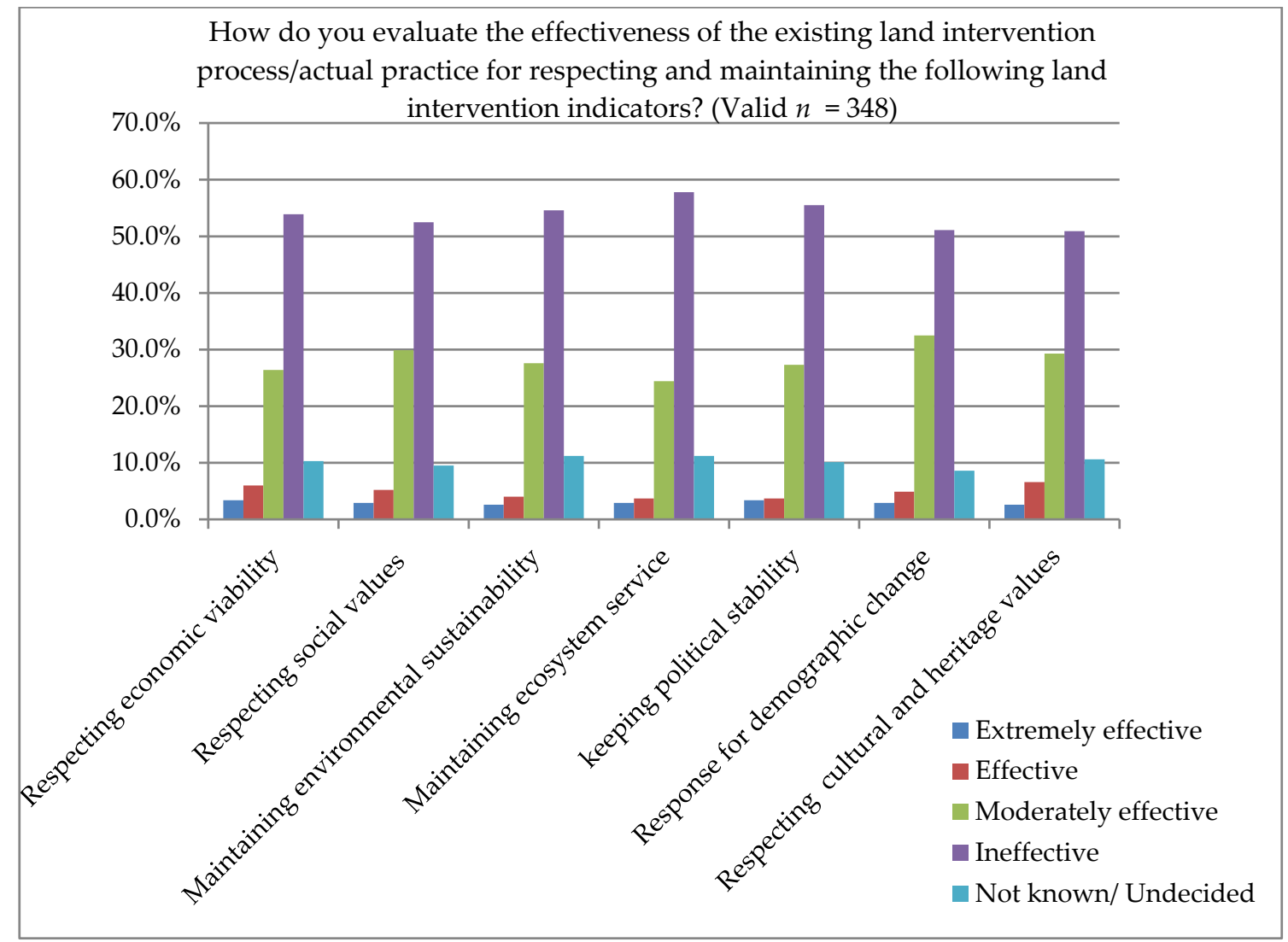

Figure 7. Effectiveness of the existing land intervention practices.

The extent and levels of peri-urban land use conflict are also high in the study area. As presented in Figure 8,39\%, 32\%, and 15\% of the respondents perceived that the extent and levels of peri-urban land use conflicts are extremely high, high, and medium, respectively. Only $10 \%$ of the respondents argued that the extent and level of the existing peri-urban land use conflicts are insignificant/low. The remaining $4 \%$ of the sample household respondents are not in a position to argue on the extent and levels of the existing peri-urban land use conflicts.



Figure 8. Households perception on the extent and levels of the existing peri-urban land use conflict.

As presented in Table 6 below, sample households were also asked to evaluate the impacts of the existing peri-urban land use intervention processes on the livelihoods of peri-urban local communities. The response ranges from 5 to 1 -strongly agree to strongly disagree, respectively. The maximum 
and minimum responses are 5 and 1. The mean response is 4.32 and the Std. deviation is 0.810 . The descriptive analysis here indicated that the existing peri-urban land intervention process has a negative impact on the livelihood of local communities. As the std. deviation value indicates there is less dispersion/deviation of response from the mean response. Similarly, the majority of sample household respondents agreed that the existing peri-urban land use intervention process is affecting the sustainability of peri-urban ecosystem services. Statistically, the mean response is 4.06 and the std. deviation is 0.932. In addition, the descriptive analysis indicated that the existing land intervention process and peri-urban land use conflict is affecting the development of infrastructure in the area. The mean response for this is 4.05 and the std. deviation is 0.930 . The std. deviation value here shows less dispersion/deviation of response from the mean response.

In the same way, the existing peri-urban land use conflict and land intervention process are affecting the socio-cultural values of local communities. Statistically, the mean response is 4.04 and the std. deviation is 0.915 . The std. deviation value here shows less dispersion/deviation of response from the mean response. Likewise, the majority of the respondents claimed that the existing land use intervention and attributed land use conflicts are leading to the displacement of local communities. In this regard, the mean response is 4.24 and the std. deviation is 0.891 . The std. deviation value here shows less dispersion of response from the mean response. Additionally, the majority of the respondents agreed that the existing peri-urban land use conflict and land intervention process are creating political instabilities. The statistical mean response is 4.23 and the std. deviation is 0.878 . Similarly, most of the respondents agreed that the existing land use intervention processes brought social crises, with a statistical mean response of 4.30 and std. deviation of 0.883 . The std. deviation value here shows less dispersion of response from the mean response. The survey analysis result also shows that the existing peri-urban land use intervention process is trigger corruption and tenure insecurity (see the statistical analysis value in Table 6). All this implies that the existing peri-urban land use challenges, in general, are highly connected with the limitations of the existing land intervention processes. These limitations have numerous impacts on the economic, socio-cultural, environmental, and political dimensions of the land.

Concerning the land intervention processes, the findings of the study support the arguments of Mohammed et al. [92]. In this regard, Mohammed et al. [92] argued that the processes of land intervention in Ethiopia are "neither participatory nor supportive to local communities". This means that local communities rarely participate in the land intervention processes, and in many cases, the government expropriates landholders with insufficient compensation [20]. Another study conducted by Deininger et al. [93], Engida [24] and Adam [25] also argued that the Ethiopian land intervention process followed mainly a top-down approach, often with little connection to reality. A crucial result of this leads to expansions of informal built-ups, land use dynamics and conflicts over land. In addition, Lombard [66] and Adam [70] argued that the land use transformation from rural to urban settings is always connected with problems like differences in tenure and administrative systems and these lead to disputes, contestation and, in some cases, violence. Both from spatial and socio-economic data analysis and discussions so far, it is possible to conclude that the existing peri-urban land intervention framework of Ethiopia is not congruent and appropriate enough to monitor and control the spatial expansions of built-ups and unwanted land use dynamics. This inevitably creates problems on the local communities, governments and the ecology of local environments, and this context calls for effective land use management policies. 
Table 6. Impacts of the existing peri-urban land use intervention process.

\begin{tabular}{|c|c|c|c|c|c|c|c|c|c|c|c|c|c|}
\hline \multicolumn{14}{|c|}{ How Do You Evaluate the Impacts of the Existing Peri-Urban Land Use Intervention Processes? (Valid $n=348$ ) } \\
\hline \multicolumn{2}{|c|}{ Indicators } & $\begin{array}{l}\text { Affecting the } \\
\text { Livelihoods of } \\
\text { Peri-Urban } \\
\text { Local } \\
\text { Communities }\end{array}$ & $\begin{array}{l}\text { Affecting the } \\
\text { Sustainability } \\
\text { of Ecosystem } \\
\text { Services }\end{array}$ & $\begin{array}{c}\text { Affecting } \\
\text { Infrastructural } \\
\text { and Service } \\
\text { Development }\end{array}$ & $\begin{array}{l}\text { Affecting the } \\
\text { Socio-Cultural } \\
\text { Values of } \\
\text { Peri-Urban } \\
\text { Local } \\
\text { Communities }\end{array}$ & $\begin{array}{l}\text { Creating } \\
\text { Political } \\
\text { Instability }\end{array}$ & $\begin{array}{l}\text { Affecting } \\
\text { Economic } \\
\text { Growth }\end{array}$ & $\begin{array}{l}\text { Increasing } \\
\text { Corruption }\end{array}$ & $\begin{array}{c}\text { Trigger } \\
\text { Tenure } \\
\text { Insecurity }\end{array}$ & $\begin{array}{l}\text { Increasing } \\
\text { Gender } \\
\text { Inequality }\end{array}$ & $\begin{array}{l}\text { Brought } \\
\text { (Causes } \\
\text { for) } \\
\text { Poverty }\end{array}$ & $\begin{array}{c}\text { Leads to } \\
\text { (Causes for) } \\
\text { Displacement } \\
\text { of Local } \\
\text { Communities }\end{array}$ & $\begin{array}{c}\text { Brought } \\
\text { (Causes } \\
\text { for) } \\
\text { Social } \\
\text { Crises }\end{array}$ \\
\hline \multirow{5}{*}{$\begin{array}{l}\text { Frequencies } \\
\text { in }(\%)\end{array}$} & $\begin{array}{l}\text { Strongly } \\
\text { Disagree }\end{array}$ & 1.4 & 3.2 & 2.6 & 2.3 & 2 & 0.9 & 1.1 & 1.4 & 12.1 & 3.2 & 2 & 1.1 \\
\hline & Disagree & 3.2 & 4.9 & 5.5 & 5.5 & 4.3 & 2.6 & 1.7 & 6.6 & 37.6 & 3.4 & 4.6 & 5.7 \\
\hline & Undecided & 3.7 & 6.9 & 8.6 & 9.5 & 4.6 & 6.3 & 3.7 & 10.1 & 10.3 & 7.5 & 4.6 & 4.3 \\
\hline & Agree & 45.4 & 52.9 & 50.6 & 51.1 & 46.8 & 46.8 & 31.9 & 47.7 & 21 & 49.7 & 45.1 & 39.9 \\
\hline & $\begin{array}{c}\text { Strongly } \\
\text { Agree }\end{array}$ & 46.3 & 32.2 & 32.8 & 31.6 & 42.3 & 43.4 & 61.6 & 34.2 & 19 & 36.2 & 43.7 & 49 \\
\hline \multirow{4}{*}{$\begin{array}{l}\text { Descriptive } \\
\text { Statistics }\end{array}$} & Min. & 1 & 1 & 1 & 1 & 1 & 1 & 1 & 1 & 1 & 1 & 1 & 1 \\
\hline & Max. & 5 & 5 & 5 & 5 & 5 & 5 & 5 & 5 & 5 & 5 & 5 & 5 \\
\hline & Mean & 4.32 & 4.06 & 4.05 & 4.04 & 4.23 & 4.29 & 4.51 & 4.07 & 2.97 & 4.12 & 4.24 & 4.30 \\
\hline & $\begin{array}{c}\text { Std. } \\
\text { Deviation }\end{array}$ & 0.810 & 0.932 & 0.930 & 0.915 & 0.878 & 0.771 & 0.753 & 0.913 & 1.354 & 0.920 & 0.891 & 0.883 \\
\hline
\end{tabular}


From the discussion so far, it is possible to note that the socio-spatial methodology applied in this research is an emerging approach in a general sense, and its application in other domains remains theoretical. This research advances the methodology to make it more empirical, i.e., the spatial results well demonstrate the impact of horizontal expansion of built-up areas and land use dynamics with different extent and magnitudes in the peri-urban lands, whereas the social analysis supports understanding of the processes of land use interventions, which can be considered as driving factors for the observed land use dynamics in the study area. The approach could be applied in other areas with similar or related context studies regardless of geographic settings to suggest a holistic land use management policy complemented with integrated follow-up alternatives. However, the economic domain/dimension of land is still loosely treated/quantified with this approach. Therefore, further studies with the integration of other economic models are essential to fully understand the economic implications of spatial patterns of informality and to suggest alternative spatial management of the peri-urban areas in line with the development agenda.

\section{Conclusions}

The main objective of this study is to conduct a socio-spatial analysis of land use dynamics and process of land intervention, and to assess to what extent the existing peri-urban land intervention processes and land use decisions are effective in combating and controlling unwanted land use changes in the peri-urban areas of Bahir Dar City. The socio-spatial methodology applied in this research is effective in capturing and monitoring both the spatial and social dimensions of land intervention and changes in land uses in peri-urban areas. The spatial results effectively demonstrate the impact of horizontal expansion of built-up areas with different extents and magnitudes across all the development corridors in the peri-urban lands, whereas the social analysis supports understanding of the processes of land use interventions that can be considered as driving factors for the observed land use dynamics in the study area. The results of land use dynamics portray that the contribution of the informal land use intervention is high for the observed dynamic and high rate of conversion of peri-urban land uses. This high rate of expansion has emerged at the expense of other land uses, and this has resulted in unplanned land use dynamics and land intervention challenges. The observed spatial patterns of built-ups in south development corridors, and following the main roads in west and east development corridors have irregular patterns, which mostly emerged without a formal land use plan. With the current annual average rates of expansions, 3960.2 ha of land will be converted to built-up areas by 2050. This circumstance creates haphazard, disputed, and unregulated land use patterns in peri-urban areas of Bahir Dar. The extent and levels of peri-urban land use dynamics and conflicts over land are also increasing through time. This is because the existing land intervention processes lack effectiveness in governing the rate and extent of unwanted land use dynamics. The attributing factors for these are associated with the existence of fragmented and unclear land use intervention processes and institutional frameworks. The results here suggest the need for an effective peri-urban land intervention framework, and clear institutional arrangements to follow-up its implementations. Further studies about the economic implications of spatial patterns of informality and alternative spatial management of the peri-urban areas in line with the development agenda are very essential. Apart from this, conducting a regular-based analysis of the spatial expansion of built-ups and other land use dynamics could be an important source of information for effective land use management and decision-making processes. Overall, the researchers concluded that a socio-spatial methodology is an effective approach needed to understand the processes of land intervention and changes in land use theoretically, and to analyze and quantify the amount of land use changes empirically.

Author Contributions: Conceptualization, A.M.W., W.T.d.V. and B.K.A.; methodology, A.M.W., W.T.d.V. and B.K.A.; software, A.M.W.; validation, A.M.W., W.T.d.V. and B.K.A.; formal analysis, A.M.W.; investigation, A.M.W.; resources, A.M.W., W.T.d.V. and B.K.A.; data curation, A.M.W.; writing-original draft preparation, A.M.W.; writing-review and editing, A.M.W., W.T.d.V. and B.K.A.; visualization, A.M.W., W.T.d.V. and B.K.A.; supervision, W.T.d.V. and B.K.A. All authors have read and agreed to the published version of the manuscript. 
Funding: This research was partially funded by the German Academic Exchange Service (DAAD) with the frame of In-Country/In-Region Scholarship Programme, and the Institute of Land Administration, Bahir Dar University, Ethiopia.

Acknowledgments: The authors acknowledge the German Academic Exchange Service (DAAD) In-Country/In-Region Scholarship Programme and the Institute of Land Administration, Bahir Dar University for supporting the research fund. We also thank proofreaders, editor-in-chief of Land Journal, and anonymous reviewers for their constructive comments and feedback.

Conflicts of Interest: The authors declare no conflict of interest.

\section{References}

1. Agunbiade, M.E.; Rajabifard, A.; Bennett, R. The dynamics of city growth and the impact on urban land policies in developing countries. Int. J. Urban Sustain. Dev. 2012, 4, 146-165. [CrossRef]

2. Alemie, B.; Zevenbergen, J.; Bennett, R. Assessing Land Governance in Ethiopian Cities (2002-2011): Lessons for the Implementation of the 2011 Urban Land Management Policy. In Proceedings of the From the Wisdom of the Ages to the Challenges of the Modern World, FIG Working Week, Sofia, Bulgaria, 17-21 May 2015.

3. UN. Realizing the Future We Want for All: Report to the Secretary-General on the UN Development Agenda; UN: New York, NY, USA, 2012; Available online: https://www.un.org/millenniumgoals/pdf/Post_2015_UNTTreport.pdf (accessed on 13 October 2019).

4. Von Der Dunk, A.; Grêt-Regamey, A.; Dalang, T.; Hersperger, A.M. Defining a typology of peri-urban land-use conflicts-A case study from Switzerland. Landsc. Urban Plan. 2011, 101, 149-156. [CrossRef]

5. Cohen, B. Urbanization in developing countries: Current trends, future projections, and key challenges for sustainability. Technol. Soc. 2006, 28, 63-80. [CrossRef]

6. UN-HABITAT. State of the World Cities 2010/2011: Bridging the Urban Divide; UN-Habitat: Nairobi, Kenya, 2010; Available online: https://sustainabledevelopment.un.org/content/documents/11143016_alt.pdf (accessed on 12 March 2018).

7. Nilsson, K.; Sick, T.; Aalbers, C.; Bell, S.; Boitier, B.; Chery, J.; Fertner, C.; Groschowski, M.; Haase, D.; Loibl, W.; et al. Strategies for Sustainable Urban Development and Urban-Rural Linkages. Eur. J. Spat. Dev. 2014, 4, 1-26.

8. Eppler, U.; Fritsche, U.; Laaks, S. Urban-Rural Linkages and Global Sustainable Land Use; GLOBALANDS Issue Paper; International Institute for Sustainability Analysis and Strategy (IINAS): Berlin, Germany; Darmstadt, Germany, 2015.

9. UN. The 2018 Revision of World Urbanization Prospects: United Nation Population Division; Department of Economic and Social Affairs, United Nations: New York, NY, USA, 2018.

10. Freire, M.E. Urbanization and Green Growth in Africa: Green Growth Series Report No. 1. Available online: https://www.greengrowthknowledge.org/research/urbanization-and-green-growth-africa2013 (accessed on 10 July 2020).

11. Don, O. Regional Overview of the Status of Urban Planning and Planning Practice in Anglophone (Sub-Saharan) African Countries, Regional Study Prepared for Revisiting Urban Planning: Global Report on Human Settlements; UN-Habitat: Nairobi, Kenya, 2009.

12. Williamson, I.; Enemark, S.; Wallace, J.; Rajabifard, A. Land Administration for Sustainable Development; Esri Press: Redlands, CA, USA, 2010; p. 506.

13. EMoUDHC. National Report on Housing and Sustainable Urban Development; Ethiopian Ministry of Urban Development, Housing and Construction: Addis Ababa, Ethiopia, 2014; Available online: http://habitat3.org/ wp-content/uploads/National-Report-Africa-Ethiopia-Final-in-English.pdf (accessed on 1 July 2018).

14. CSA. The Federal Democratic Republic of Ethiopia Central Statistical Agency Report on Population Projection of Ethiopia; CSA: Addis Ababa, Ethiopia, 2013. Available online: http://www.csa.gov.et/ (accessed on 11 November 2018).

15. Fenta, A.A.; Yasuda, H.; Haregeweyn, N.; Belay, A.S.; Hadush, Z.; Gebremedhin, M.A.; Mekonnen, G. The dynamics of urban expansion and land use/land cover changes using remote sensing and spatial metrics: The case of Mekelle City of northern Ethiopia. Int. J. Remote Sens. 2017, 38, 4107-4129. [CrossRef]

16. Gashu, K.; Gebre-Egziabher, T. Spatiotemporal trends of urban land use/land cover and green infrastructure change in two Ethiopian cities: Bahir Dar and Hawassa. Environ. Syst. Res. 2018, 7, 8. [CrossRef] 
17. Manikandan, S. Spatial and Temporal Dynamics of Urban Sprawl Using Multi- temporal Images and Relative Shannon Entropy Model in Adama, Ethiopia. J. Adv. Res. Geo Sci. Remote Sens. 2019, 5, 48-57. [CrossRef]

18. EMoUDH; World-Bank. Ethiopia Urbanization Review: Urban Institutions for a Middle-Income Ethiopia; EMoUDH, World-Bank: Addis Ababa, Ethiopia, 2015; Available online: http://documents.worldbank.org/curated/en/ 543201468000586809/pdf/100238-WP-EUR-Box393221B-PUBLIC.pdf (accessed on 12 October 2019).

19. CSA. Federal Democratic Republic of Ethiopia Central Statistical Agency: Population Census of Ethiopia; CSA: Addis Ababa, Ethiopia, 2007. Available online: http://www.csa.gov.et/ (accessed on 11 November 2018).

20. Wubneh, M. Policies and praxis of land acquisition, use, and development in Ethiopia. Land Use Policy 2018, 73, 170-183. [CrossRef]

21. Wubie, A.M.; De Vries, W.T.; Alemie, B.K. Synthesizing the dilemmas and prospects for a peri-urban land use management framework: Evidence from Ethiopia. Land Use Policy 2021, 100, 105122. [CrossRef]

22. Adam, A.G. Informal settlements in the peri-urban areas of Bahir Dar, Ethiopia: An institutional analysis. Habitat Int. 2014, 43, 90-97. [CrossRef]

23. Fetene, M.W.; Serbeh-Yiadom, K.; Asfaw, M. A Critical Review of the Application of Planning Standards and Norms in the Planning of Bahir Dar and Hawassa Cities, Ethiopia. Dev. Ctry. Stud. 2014, 4, 66-79.

24. Dube, E.E. Urban planning and land management challenges in emerging towns of ethiopia: The case of arba minch. J. Urban Environ. Eng. 2013, 7, 340-348. [CrossRef]

25. Adam, A.G. Peri-Urban Land Tenure in Ethiopia. Ph.D. Thesis, Royal Institute of Technology (KTH), Stockholm, Sweden, 2014.

26. WHO; UN-Habitat. Global Report on Urban Health: Equitable, Healthier Cities for Sustainable Development; WHO Library Cataloguing-in-Publication Data; WHO and UN-Habitat: Geneva, Switzerland, 2016; ISBN 9789241565271.

27. Holden, S.T.; Bezu, S. Preferences for land sales legalization and land values in Ethiopia. Land Use Policy 2016, 52, 410-421. [CrossRef]

28. Bennett, R.M.; Alemie, B.K. Fit-for-purpose land administration: Lessons from urban and rural Ethiopia. Surv. Rev. 2016, 48, 11-20. [CrossRef]

29. Enemark, S. Building Land Information Policies. In Proceedings of the UN, FIG, PC IDEA Inter-regional Special Forum on The Building of Land Information Policies in the Americas, Aguascalientes, Mexico, 26-27 October 2004.

30. Adam, A.G. Land Tenure in the Changing Peri-Urban Areas of Ethiopia: The Case of Bahir Dar City. Int. J. Urban Reg. Res. 2014, 38, 1970-1984. [CrossRef]

31. Debolini, M.; Valette, E.; François, M.; Chéry, J.-P. Mapping land use competition in the rural-urban fringe and future perspectives on land policies: A case study of Meknès (Morocco). Land Use Policy 2015, 47, 373-381. [CrossRef]

32. Ruoso, L.-E.; Plant, R. A politics of place framework for unravelling peri-urban conflict: An example of peri-urban Sydney, Australia. J. Urban Manag. 2018, 7, 57-69. [CrossRef]

33. Gomes, S.L.; Hermans, L.M. Institutional function and urbanization in Bangladesh: How peri-urban communities respond to changing environments. Land Use Policy 2018, 79, 932-941. [CrossRef]

34. Admasu, T.G. Urban land use dynamics, the nexus between land use pattern and its challenges: The case of Hawassa city, Southern Ethiopia. Land Use Policy 2015, 45, 159-175. [CrossRef]

35. Admasu, W.F.; Van Passel, S.; Minale, A.S.; Tsegaye, E.A.; Azadi, H.; Nyssen, J. Take out the farmer: An economic assessment of land expropriation for urban expansion in Bahir Dar, Northwest Ethiopia. Land Use Policy 2019, 87, 104038. [CrossRef]

36. Haregeweyn, N.; Fikadu, G.; Tsunekawa, A.; Tsubo, M.; Meshesha, D.T. The dynamics of urban expansion and its impacts on land use/land cover change and small-scale farmers living near the urban fringe: A case study of Bahir Dar, Ethiopia. Landsc. Urban Plan. 2012, 106, 149-157. [CrossRef]

37. UN-GGIM. UN-GGIM (UN-Global Geospatial Information Management) Inter-Agency and Expert Group on the Sustainable Development Goal Indicators (IAEG-SDGS) Working Group Report on Geospatial Information. 2013. Available online: http://ggim.un.org/UNGGIM-wg6/ (accessed on 14 March 2018).

38. McCall, M.K.; Dunn, C.E. Geo-information tools for participatory spatial planning: Fulfilling the criteria for 'good' governance? Geoforum 2012, 43, 81-94. [CrossRef] 
39. Yeh, A. Decision Support with Geographic Information Systems. In Decision Support for Sustainable Development: A Resource Book of Methods and Applications; Kersten, G., Mikolajuk, Z., Yeh, A., Eds.; International Development Research Centre, Kluwer Academic Publishers: Norwell, MA, USA, 2000; pp. 53-70.

40. Navarro-Cerrillo, R.M.; Palacios-Rodríguez, G.; Rumbao, I.C.; Lara, M.; Bonet, F.J.; Mesas-Carrascosa, F. Modeling Major Rural Land-Use Changes Using the GIS-Based Cellular Automata Metronamica Model: The Case of Andalusia (Southern Spain). ISPRS Int. J. Geo-Inf. 2020, 9, 458. [CrossRef]

41. Tuladhar, A. Innovative Uses of Remote Sensing Image for Pro Poor Land Management. In Land Administration: The Path to Tenure Security, Poverty Alleviation and Sustainable Development: Land Administration seSsions ITC Lustrum Conference, Spatial Information for Civil Society, Capacity Building for the International Geo-Information Society; Kalf, J., Ed.; International Institute for Geo-Information Science and Earth Observation: Enschede, The Netherlands, 2006; pp. 81-96.

42. Kansu, O.; Gazioglu, S. The Availability of Satellite Image data in digital Cadastral Map Production. In Proceedings of the Shaping the Change, Munich, Germany, 8-13 October 2006.

43. Ruiz-Tagle, J. A Theory of Socio-spatial Integration: Problems, Policies and Concepts from a US Perspective. Int. J. Urban Reg. Res. 2012, 37, 388-408. [CrossRef]

44. Pribadi, D.O.; Pauleit, S. The dynamics of peri-urban agriculture during rapid urbanization of Jabodetabek Metropolitan Area. Land Use Policy 2015, 48, 13-24. [CrossRef]

45. Tacoli, C. The links between urban and rural development. Environ. Urban 2003, 15, 1-12. [CrossRef]

46. Sapena, M.; Ruiz, L.A.; Taubenböck, H. Analyzing Links between Spatio-Temporal Metrics of Built-Up Areas and Socio-Economic Indicators on a Semi-Global Scale. ISPRS Int. J. Geo-Inf. 2020, 9, 436. [CrossRef]

47. Wei, Y.D.; Ye, X. Urbanization, urban land expansion and environmental change in China. Stoch. Environ. Res. Risk Assess. 2014, 28, 757-765. [CrossRef]

48. FIG-Commission-3. Rapid Urbanization and Mega Cities: The Need for Spatial Information Management; International Federation of Surveyors (FIG): Copenhagen, Denmark, 2010.

49. Floater, G.; Rode, P.; Friedel, B.; Robert, A. Steering Urban Growth: Governance, Policy and Finance; London School of Economics and Political Science: London, UK, 2014.

50. Banzhaf, E.; Kabisch, S.; Knapp, S.; Rink, D.; Wolff, M.; Kindler, A. Integrated research on land-use changes in the face of urban transformations-An analytic framework for further studies. Land Use Policy 2017, 60, 403-407. [CrossRef]

51. Enoguanbhor, E.C.; Gollnow, F.; Nielsen, J.O.; Lakes, T.; Walker, B.B. Land Cover Change in the Abuja City-Region, Nigeria: Integrating GIS and Remotely Sensed Data to Support Land Use Planning. Sustainability 2019, 11, 1313. [CrossRef]

52. Hu, Y.; Kong, X.; Zheng, J.; Sun, J.; Wang, L.; Min, M. Urban Expansion and Farmland Loss in Beijing during 1980-2015. Sustainability 2018, 10, 3927. [CrossRef]

53. Robinson, G.M.; Song, B. Transforming the Peri-Urban Fringe in China: The Example of Xi'an-Xianyang. Sustainability 2018, 10, 3932. [CrossRef]

54. Medeiros, E.; Van Der Zwet, A. Sustainable and Integrated Urban Planning and Governance in Metropolitan and Medium-Sized Cities. Sustainability 2020, 12, 5976. [CrossRef]

55. UN-WESS. Sustainable Development Challenges; United Nations publication: New York, NY, USA, 2013; Available online: https://sustainabledevelopment.un.org/content/documents/2843WESS2013.pdf (accessed on 12 November 2018).

56. Tian, Y.; Wang, L. The Effect of Urban-Suburban Interaction on Urbanization and Suburban Ecological Security: A Case Study of Suburban Wuhan, Central China. Sustainability 2020, 12, 1600. [CrossRef]

57. Qiu, R.; Xu, W. Modes of land development in Shanghai. Land Use Policy 2017, 61, 475-486. [CrossRef]

58. UNPD. World Population Prospects the 2010 Revision; United Nations: New York, NY, USA, 2011; Volume I.

59. UN-Habitat. The State of African Cities: Re-Imagining Sustainable Urban Transitions; UN-Habitat: Nairobi, Kenya, 2014.

60. Karg, H.; Hologa, R.; Schlesinger, J.; Drescher, A.; Kranjac-Berisavljevic, G.; Glaser, R. Classifying and Mapping Periurban Areas of Rapidly Growing Medium-Sized Sub-Saharan African Cities: A Multi-Method Approach Applied to Tamale, Ghana. Land 2019, 8, 40. [CrossRef]

61. Wu, Y.; Zhang, X.; Shen, L. The impact of urbanization policy on land use change: A scenario analysis. Cities 2011, 28, 147-159. [CrossRef] 
62. Gwan, A.S.; Kimengsi, J.N. Urban Expansion and the Dynamics of Farmers' Livelihoods: Evidence from Bamenda, Cameroon. Sustainability 2020, 12, 5788. [CrossRef]

63. Lwasa, S. Managing African Urbanization in the Context of Environmental Change. Interdisciplina 2014, 2, 263-280. [CrossRef]

64. Wu, Y.; Tao, Y.; Yang, G.; Ou, W.; Pueppke, S.; Sun, X.; Chen, G.; Tao, Q. Impact of land use change on multiple ecosystem services in the rapidly urbanizing Kunshan City of China: Past trajectories and future projections. Land Use Policy 2019, 85, 419-427. [CrossRef]

65. Akubia, J.E.K.; Ahmed, A.; Bruns, A. Assessing How Land-Cover Change Associated with Urbanisation Affects Ecological Sustainability in the Greater Accra Metropolitan Area, Ghana. Land 2020, 9, 182. [CrossRef]

66. Lombard, M. Land conflict in peri-urban areas: Exploring the effects of land reform on informal settlement in Mexico. Urban Stud. 2016, 53, 2700-2720. [CrossRef]

67. EU. Land Policy Guidelines: Guidelines for Support to Land Policy Design and Land Policy Reform Processes in Developing Countries; European Union: Brussels, Belgium, 2004.

68. Barnard, S.; Elliott, M. The 10-tenets of adaptive management and sustainability: An holistic framework for understanding and managing the socio-ecological system. Environ. Sci. Policy 2015, 51, 181-191. [CrossRef]

69. FDRE-Urban-Land-Lease-Proc. Federal Democratic Republic of Ethiopia Urban Lands Lease Holding Proclamation No. 721/2011; Federal Negarit Gazette: Addis Ababa, Ethiopia, 2011.

70. Adam, A.G. Peri-urbanization and New Built-up Property Formation Process in the Peri-urban Areas of Ethiopia. JLAEA 2015, 3, 328-345.

71. Rural-Land-Administration-and-Use-Proc. Federal Democratic Republic of Ethiopia Rural Land Administration and Land Use Proclamation No. 456/2005; Federal Negarit Gazette: Addis Ababa, Ethiopia, 2005.

72. FDRE-Constitution. Constitution of Federal Democratic Republic of Ethiopia, Proclamation No.1/1995; Fed. Neg. Gaz. 1st year No.1; Federal Negarit Gazetta: Addis Ababa, Ethiopia, 1995.

73. Ambaye, D.W. Land Rights and Expropriation in Ethiopia; Springer International Publishing: Cham, Switzerland, 2015. [CrossRef]

74. Meteorological-Agency. Report of Temperature and Rainfall Data; National Meteorological Agency of Ethiopia, Bahir Dar Branch: Bahir Dar, Ethiopia, 2019.

75. FAO. World Soil Database; Food and Agriculture Organization of the United Nations: Rome, Italy, 1984.

76. IMF. Country Report No. 20/29 of the Federal Democratic Republic of Ethiopia; International Monetary Fund: Washington, DC, USA, 2020; Available online: http://www.imf.org (accessed on 27 October 2020).

77. Alemie, B.K.; Bennett, R.; Zevenbergen, J. A socio-spatial methodology for evaluating urban land governance: The case of informal settlements. J. Spat. Sci. 2015, 60, 1-21. [CrossRef]

78. Cochran, W.G. Sampling Techniques, 2nd ed.; John Wiley and Sons, Inc.: New York, NY, USA, 1963.

79. Yamane, T. Statistics: An Introductory Analysis, 2nd ed.; Harper and Row: New York, NY, USA, 1967.

80. Israel, G. Determining Sample Size; Institute of Food and Agricultural science, University of Florida: Gainesville, FL, USA, 2003.

81. Krueger, R.; Casey, M. Focus Groups: A Practical Guide for Applied Research, 5th ed.; Sage Publications Inc.: Thousand Oaks, CA, USA, 2014.

82. Rabiee, F. Focus-group interview and data analysis. Proc. Nutr. Soc. 2004, 63, 655-660. [CrossRef]

83. Lillesand, T.; Kiefer, R. Remote Sensing and Image Interpretation, 4th ed.; Wiley and Sons: New York, NY, USA, 2000.

84. Abburu, S.; Golla, S.B. Satellite Image Classification Methods and Techniques: A Review. Int. J. Comput. Appl. 2015, 119, 20-25. [CrossRef]

85. FAO. AFRICOVER Land Cover Classification; Food and Agriculture Organisation of the United Nations: Rome, Italy, 1997; Available online: http://www.fao.org/3/a-bd854e.pdf (accessed on 10 August 2019).

86. Jansen, L.J.M. Harmonization of land use class sets to facilitate compatibility and comparability of data across space and time. J. Land Use Sci. 2006, 1, 127-156. [CrossRef]

87. Aksoy, S. Spatial Techniques for Image Classification. Image Process. Remote Sens. 2008, 1-28. Available online: https://www.researchgate.net/publication/228937024 (accessed on 27 October 2020). [CrossRef]

88. Congalton, R.G. A review of assessing the accuracy of classifications of remotely sensed data. Remote Sens. Environ. 1991, 37, 35-46. [CrossRef]

89. Rovai, A.; Baker, J.; Ponton, M. Social Science Research Design and Statistics: A Practitioner's Guide to Research Methods and IBM SPSS Analysis, 2nd ed.; Watertree Press: Chesapeake, VA, USA, 2014. 
90. Mawenda, J.; Watanabe, T.; Avtar, R. An Analysis of Urban Land Use/Land Cover Changes in Blantyre City, Southern Malawi (1994-2018). Sustainability 2020, 12, 2377. [CrossRef]

91. Tian, Y. Mapping Suburbs Based on Spatial Interactions and Effect Analysis on Ecological Landscape Change: A Case Study of Jiangsu Province from 1998 to 2018, Eastern China. Land 2020, 9, 159. [CrossRef]

92. Kosa, A.; Juhar, N.; Kute, I.M. Urbanization in Ethiopia: Expropriation Process and Rehabilitation Mechanism of Evicted Peri-Urban Farmers (Policies and Practices). Int. J. Econ. Manag. Sci. 2017, 6, 1-9. [CrossRef]

93. Deininger, K.; Selod, H.; Burns, A. The Land Governance Assessment Framework: Identifying and Monitoring Good Practice in the Land Sector; World Bank: Washington, DC, USA, 2012.

Publisher's Note: MDPI stays neutral with regard to jurisdictional claims in published maps and institutional affiliations.

(C) 2020 by the authors. Licensee MDPI, Basel, Switzerland. This article is an open access article distributed under the terms and conditions of the Creative Commons Attribution (CC BY) license (http://creativecommons.org/licenses/by/4.0/). 